\title{
The Effect of Application of Project Methods Toward Children's Confidence Age 5-6 Years
}

\author{
Nurmaniah $^{1 *}$, Peny Husna Handayani ${ }^{2}$, Septyka Alovani Br Karo ${ }^{3}$ \\ ${ }^{1,2,3)}$ Faculty of Education, Universitas Negeri Medan, Indonesia \\ *nurmaniah14@yahoo.com
}

\begin{abstract}
This study aims to determine the effect of the application of project method on the children's confidence aged 5-6 years at TK Santa Lusia Medan. Design of this study is true experimental design in the form of post-test only control. The population were all kindergarten children B at Santa Lusia Medan, consisting of 4 classes and total number 130 children. Results of data analysis obtained the average value of children who use the project method (matching geometric shapes) of children's confidence is (14.16) with the highest value of 16 and the lowest value of 12 . While the average value of children who use the demonstration method (matching geometric form) of children's confidence (11.19) with the highest value 12 and the lowest value 9. It was concluded that children's confidence is better to use the project method to the child's self-confidence than children who use the demonstration method. From the hypothesis test, can be said that there is an influence of the application of the project method on the ability of children's confidence.
\end{abstract}

Keywords: project method, children's confidence

\section{Introduction}

Early childhood education is a form of education aimed at children from birth until the age of six. Therefore, giving attention to education, especially Early Childhood Education, is one of the brightest steps in preparing a superior generation that will become the nation's next generation [1]. Early childhood education is done through providing a stimulus to help the growth and development of children.

Currently the need for Early Childhood Education is growing rapidly, as evidenced by the many Early Childhood Education institutions established from urban to rural areas. With the establishment of this Early Childhood Education institution, it is hoped that adults, especially teachers, can provide stimulus and support capable of developing all aspects of child development [2,3]. Child development aspects include aspects of cognitive development, language, physical / motor, social emotional, moral values and religion. These aspects have indicators including the scope of emotional social development; social-emotional development has several dimensions, including confidence [4]

Confidence is not born. Self-confidence starts to be grown and stimulated from an early age. Self-confidence is important for children to live life. This statement is in line with states that self-confidence will be the capital of children's success in the future $[5,6]$. He will get along faster, faster to master expertise, better prepared for problems. Aprianti [1] said that when a child has confidence, he will be able to master certain fields and more easily absorb things that are informed to him in the future. As an adult the child will be better able to deal with life's challenges to the fullest without asking excessive help from others 
From birth the child is involved in the dynamic process of being himself. The child continues to develop into a whole person with character, personality, and value system with unique physical, cognitive, language, social, emotional and creative arrangements. This is an exciting process that always develops for life, but these stages are perhaps the most important, because they determine the pattern for the next process [7]. An important aspect of a child's growing personality is the development of his self-concept: his self-awareness which includes both his self-image (his own internal image and self-esteem (his awareness of self-worth) that influences his self-confidence in children [8].

Based on the results of observations made by researchers at Saint Lucia's Kindergarten, there are still children who have a lack of confidence. This is shown by the lack of confidence of children to do the activities given by the teacher, children cannot stand alone, they always say "Ma'am, I can't" when going to work on assignments. There are still some children who cannot get along with their friends; they prefer to be spectators when their friends are playing. In addition, when children do group work, they are often unable to accept criticism, suggestions or opinions of other friends, when children are given input from other friends, they cannot accept and end up crying. This can be seen from the observations of researchers conducted in Santa Lusia Kindergarten that many children are too dependent on others, both to their peers and to their teachers. Through dependence on others, it can influence the development of a child's own self-confidence in his abilities. Some things that cause the low ability of self-confidence of children due to several factors, one of which is the method used in the learning process lacks to develop children's confidence abilities, one of which is the project method. In this regard, the project method is not always used in learning given to children [9].

There are various methods that can improve the ability of self-confidence of children. One of them is through the use of project methods. According Istarani [2,5] the project method is one of providing learning experiences by confronting children with everyday problems that must be solved in groups.

\section{Research Method}

This study is experimental research used true experimental design in the form of Posttest Only Control Design. This experimental study grouped the research sample into two groups, each as an experimental class the project method was applied and the control class applied the demonstration method [10].

The sampling technique will be done by random sampling. Namely by selecting samples in a random way, because the population has the same characteristics, especially in terms of the age of each age 5-6 years, in addition to the age of the child can also be seen from the ability of children. So the method of sampling is done by inserting paper into a bottle where the paper is labeled B1, B2, B3, B4, and then the bottle is shaken, after being shaken then one paper is taken to be a control class, and then one more paper is taken to be an experimental class so that B1 class of 31 people for the experimental class and B2 class of 31 people for the control class is obtained. This research was conducted in two classes with different treatments, class B2 as an experimental class, namely a class that learning activities using the project method, while class B1 as a control that is a class using learning methods demonstration.

Data collection techniques carried out by structured observation. Sugiono [10] said structured observations are observations that are systematically designed, about what will be observed, when and where it is. This research instrument uses observation guidelines. The observation guide contains a list of activities or behaviors that may arise and will be observed. 
In the process of observation, the observer only gives a check list $(\sqrt{ })$ to the score obtained through the observation guidelines that have been prepared. From the results of observations made, the data obtained about the ability of children with confidence through learning methods.

Table 1. Lattice Instrument for Assessing Children's Self-Confidence Ability

\begin{tabular}{|c|c|c|}
\hline Variable & Indicators & Descriptor \\
\hline \multirow[t]{3}{*}{$\begin{array}{l}\text { Confidence } \\
\text { Ability }\end{array}$} & $\begin{array}{l}\text { The child does not ask } \\
\text { for help matching } \\
\text { geometric shapes }\end{array}$ & $\begin{array}{l}\text { a. Children want to match geometric shapes } \\
\text { b. Children are able to match geometric shapes } \\
\text { according to their respective tasks } \\
\text { c. Children can match geometrical shapes correctly } \\
\text { d. The child is able to match geometrical shapes } \\
\text { without asking the teacher for help }\end{array}$ \\
\hline & $\begin{array}{l}\text { Children are able to } \\
\text { communicate }\end{array}$ & $\begin{array}{l}\text { a. Children are able to communicate well with } \\
\text { friends } \\
\text { b. Have a calm attitude (not nervous when doing } \\
\text { something) } \\
\text { c. Children dare to ask the teacher or friend if } \\
\text { something is not understood } \\
\text { d. Children are able to express their opinions }\end{array}$ \\
\hline & $\begin{array}{l}\text { Children are able to } \\
\text { work together in } \\
\text { working on beam } \\
\text { projects }\end{array}$ & $\begin{array}{l}\text { a. Children can work together with friends } \\
\text { b. The child knows the part that must be done in the } \\
\text { project } \\
\text { c. Children can receive criticism from others } \\
\text { d. Children are able to help friends who are } \\
\text { struggling }\end{array}$ \\
\hline
\end{tabular}

\section{Results and Discussion}

The results of observations in the experimental class contained an average grade of 3.54 with a sample of 31 children. The class used for the experimental class is class B1. The following is a table of data on the ability of children's confidence in the experimental class. From data analysis known that the ability of self-confidence of children aged 5-6 years in kindergarten Santa Lucia is classified as very good with an average $=3.54$. For more clearly about the table above, it can be described in graphical form as follows:

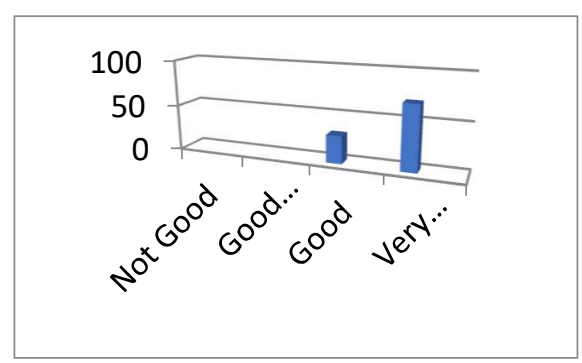

Figure 1. Ability of a Child's Self-confidence using Project Method.

The graph above can be seen that the ability of children's confidence in the Good score is $30 \%$ and in the Very Good score there is $70 \%$. The results of observations in the control class 
contained an average grade of 2.76 with a sample of 31 children. The class used for the control class is class B2.

From the data analysis shows that the level of self-confidence ability of children aged 5-6 years in the Santa Lusia Kindergarten Medan in the control class is quite good with an average value of 2.76. Below is a data graph for the control class.

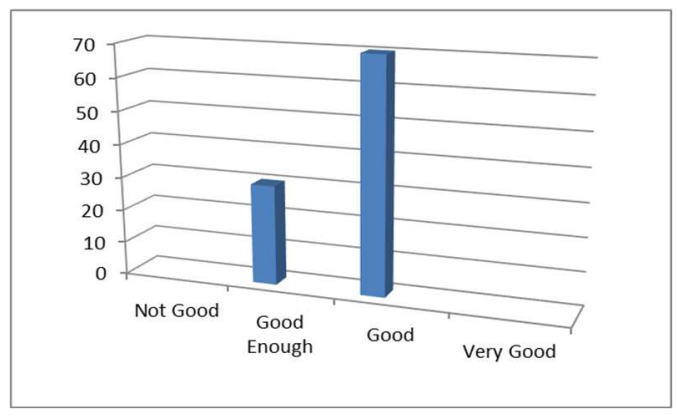

Figure 2. Ability of Child's Self-confidence using Demonstration Method

Based on the graph above it can be seen that the ability of self-confidence of children on the Good Enough score is 30\% and children who get the Good score are $70 \%$.Based on observations showing that the use of project methods by matching geometric shapes can provide more significant results on the ability of children's confidence when compared to classes that use demonstration methods to match geometric shapes.

There are significant differences between class data using the project method by matching geometric shapes and class data using the demonstration method. In the class that carries out project method activities by matching the geometric shape the average of the child's ability to confident amounts to 3.54 and the class using demonstration method matching 2.76 . There is difference in the average value of children's confidence as 0.78 . T-test results are presented in Table 2.

Table 2. Hypothesis Test Calculation Results with t-Test

\begin{tabular}{llcrrr}
\hline No & \multicolumn{1}{c}{ Group of Data Research } & Average & $t_{\text {count }}$ & $t_{\text {table }}$ & Conclusion \\
\hline 1 & $\begin{array}{l}\text { Experiment Class with project } \\
\text { method (matching geometric } \\
\text { shapes) }\end{array}$ & 14,16 & & & \\
\hline 2 & $\begin{array}{l}\text { Observation of Control Class with } \\
\text { demonstration method } \\
\text { (matching geometric shapes) }\end{array}$ & 11,19 & 9,31 & 1,670 & $\begin{array}{l}\text { There is a } \\
\text { difference The } \\
\text { significant }\end{array}$ \\
\hline
\end{tabular}

Based on the results of the calculation of the hypothesis test, the value of $t_{\text {coun }} \mathrm{t}$ is 9.31 compared to the value of $\alpha=0.05$ and the denominator $\mathrm{db}=60, \mathrm{t}$ table $=1.670$. Thus Ho is rejected and $\mathrm{Ha}$ is accepted, so it can be stated that there is a significant effect of the project method on the confidence ability of children in kindergarten Saint Lucia Medan.

After different treatments, an average score of children's confidence in the experimental class was obtained, 3.54 while in the control class 2.76. From the observations of the two samples obtained a difference of 0.78 so that from the data there are differences in the ability of children's confidence in the experimental class and control class. This is due to the application of the project method of matching geometric shapes that have a variety of attractive shapes and colors so as to make children aged 5-6 years more interested in doing 
activities that develop children's self-confidence ability because they can foster children with the habit of applying knowledge, attitudes and skills in everyday life in an integrated manner. Besides the project approach also emphasizes the active participation of children in learning that increases children's confidence, this is in accordance with the opinion of Isjoni [4] project method is one form of activity in problem solving that has very practical value important for the personal development of children, as well as developing the skills to live everyday life and this method is one that is suitable for development, especially cognitive, social, motor, creative, and emotional children. So based on research that has been done at the Santa Lusia Kindergarten that the project method gives a positive influence on the ability of children's confidence. The results of this study reinforce theories of the development of children's selfage $[4,6,7]$ and the results of previous studies [11].

\section{Conclusion}

Based on the results of research that has been done, it can be concluded that the project method is a method that requires the activeness and cooperation of children by providing opportunities in the form of giving an activity that is done in groups to achieve a common goal, so that children will try to interact, work together, with friends so that can complete activities. Analysis of the data obtained the average value of children who use the project method (matching geometric shapes) to the child's confidence is (14.16) with the highest value of 16 and the lowest value of 12. While the average value of children who use the demonstration method (matching geometric shapes) ) to the child's confidence is (11.19) with the highest value 12 and the lowest value 9. It was concluded that the confidence of the stimulated child is better by using the project method (matching geometric shapes) rather than using the demonstration method (matching geometric shapes). From the hypothesis test can be said that there is a significant influence on the application of project methods to the child's self-confidence ability.

\section{References}

[1] Aprianti, Yofia. (2013). Menumbuhkan Kepercayaan Diri Melalui Kegiatan Bercerita. Jakarta: Indeks

[2] Istarani (2012). Kumpulan 39 Metode Pembelajaran. Medan: Iscom.

[3] Isjoni. (2008). Model-model Pembelajaran Mutakhir.Yogyakarta: Pustaka Pelajar.

[4] Beaty Janice J. (2013). Observasi Perkembangan Anak Usia Dini. Jakarta: Kencana.

[5] Djamarah B Syaiful (2010). Strategi Belejar Mengajar. Jakarta: RinekaCipta.

[6] Hall Janet. (2003). Cara Efektif Membangun Keberaniandan Rasa Percaya Diri PutraPutri Anda. Jakarta: Ladang Pustaka \& Intimedia.

[7] Hamid Sholeh, (2011). Metode Edu Trainment, Jogyakarta: Diva Press.

[8] Hatiman, (2012). Interaksi dan Motivasi Belajar Mengajar. Jakarta: Rajawali.

[9] Lie Anita, (2003). Cara Menumbuhkan Percaya Diri Anak. Jakarta: Elex Media Komputindo.

[10] Sugiono. (2013). Metodologi Penelitian Kuantitatif, Kualitatif Dan R\&D. Bandung: Alfabeta.

[11] Moeslichatoen. (2004). Metode Pembelajaran di TK. Malang: Departemen Pendidikan dan Kebudayaan Direktorat Jendral Pendidikan Tinggi Proyek Pendidikan Tenaga Akademik. 